\title{
CLINIC-Q MEDICAL AND DENTAL DEVELOPMENT BUSINESS STRATEGY WITH SUSTAINABLE DEVELOPMENT PERSPECTIVE
}

\author{
Iik Yani Hidayati ${ }^{1 *}$, Muhammad Firdaus ${ }^{2}$, Bunasor Sanim ${ }^{3}$ \\ ${ }^{1}$ Magister of Management and Business, Business School, IPB University, 16218 \\ ${ }^{2}$ Department of Management, Faculty of Economics and Management, IPB University, \\ Bogor, 16680 \\ ${ }^{3}$ Department of Management and Business, Faculty of Management and Business, IPB \\ University, Bogor, 16680 \\ *Corresponding author: iikyanihidayati@gmail.com
}

\begin{abstract}
This research is research related to the formation of strategy development in a clinic. The Discussion is aimed at the theme of the clinical business development strategy. In addition, the discussion will use a sustainable business development perspective. Data collected is sourced from experts with different expertise. Assessing experts were asked to provide a questionnaire assessment related to the internal environment and the external environment of the clinic. Financial statements used are from 2015 to 2017. Assessment results from experts are then adjusted to the IE Matrix to obtain the company's strategy formulation. After obtaining the strategy formulation, the best strategy for the clinic was conducted using the QSPM approach. Results of the study show that the position of the clinic-Q Medical \& Dental is in quadrant 1 which means the clinic is recommended for development. In addition, based on the assessment of QSPM, it is found that the company can implement product development, integration and market penetration. On the other hand, clinics are also advised to continue to increase their role in protecting the environment.
\end{abstract}

Keyword: Clinic, Development, SDGs, Strategy

\begin{abstract}
Abstrak
Penelitian ini merupakan penelitian terkait dengan pembentukan pengembangan strategi disuatu klinik. Pembahasan ditujukan pada tema strategi pengembangan bisnis klinik. Selain itu dalam pembahasannya akan digunakan perspektif pembangunan bisnis yang berkelanjutan. Data yang dikumpulkan bersumber dari ahli dengan keahlian berbeda. Para ahli menilai diminta untuk memberikan penilaian kuesioner terkait dengan lingkungan internal dan lingkungan eksternal dari klinik. Adapun laporan keuangan yang digunakan adalah sejak tahun 2015 hingga tahun 2017. Hasil penilaian dari para ahli kemudian disesuaikan pada IE Matrix untuk mendapatkan formulasi strategi perusahaan. Setelah didapat formulasi strategi kemudian dilakukan pemilihan strategi terbaik bagi klinik dengan menggunakan pendekatan QSPM. Hasil penelitian menunjukan bahwa posisi Klinik-Q Medical \& Dental berada di kuadran 1 yang berarti klinik direkomendasikan untuk melakukan pengembangan. Selain itu berdasarkan penilaiain QSPM didapat bahwa perusahaan dapat mengimplemtasikan pengembangan
\end{abstract}


produk, integrasi dan penetrasi pasar. Disisi lain klinik juga disarankan untuk terus meningkatkan peran dalam menjaga lingkungan.

Kata kunci: Klinik, Pengembangan, SDGs, Strategi

\section{Introduction}

It is known that the service sector is supported by a health service business that has a vital function for the community. The health services business is divided into five types of entities, namely hospitals, clinics, private doctor practices, pharmacies, and laboratories. The five entities, of course, play an important function in business to meet consumer needs. According to the Ministry of Health Indonesia, the ratio of the existence of health center has exceeded the need, but in West Java the existence of a health center is still very much needed, now in West Java every health center must be able to cover more than 40.000 residents (Kementerian Keseahatan, 2015). Health services are an integral part of national development. In the Law No. 23 of 1992 concerning health stipulated that health is a state of well-being from the body, soul, and social which allows every person to live productively socially and economically. The goal of the health development is to increase awareness, willingness and ability to live healthy for everyone in order to realize optimal public health degree (Kementerian Keseahatan, 2018).

Health services that are directly related are very closely related to service quality. Patients and / or families of patients have the desire to be given the best service and continue to increase. Described by De Ven (2014) who made a measure of the importance of patients in a place of treatment, it is known that the concern of staff or employees there is important to create patient satisfaction. So that it takes an effort to always meet patient expectations is the key to satisfaction. Currently the health services business is also facing tremendous pressure due to technological developments. It was explained that the patients were given the convenience of being able to find information, discuss, consult without having to come to the location and be able to register with a health unit such as a clinic or hospital. The role of information technology makes stakeholders in the health business increasingly limitless, this has a very good impact on health workers and business owners who can use it (Thimbleby, 2013). In European countries, the use of information technology can reduce the administrative costs of healthcare providers by 35 percent and provide increased comfort and satisfaction for patients (Deloitte, 2015). The government always strives to provide optimal health services, but there are other needs that become opportunities for business people to participate in providing these health services. It is known that health services in the form of clinics are very rapidly developing. It is known that the number of clinics in Jabodetabek (Jakarta, Bogor, Depok, Tangerang, and Bekasi) each year always increases. Of the five regions, Bogor is an area with an average growth of 28 percent per year.

The clinic is a smaller medical facility and only serves certain treatments and treatments and is devoted to outpatient health services, its existence in the community is very important with services that provide health care facilities whose quality is almost the same as that of a hospital. Each clinic has its advantages that can be the attraction of patients or people who need health services. Ministry of Health Regulation Number 9 of 2014 explains that clinics are businesses that fall into the category of small and medium enterprises, which must be supervised by people who have certain competencies. It is 
known that clinic-Q medical and dental is a health service that already has two branches in the city of Bogor and has been running for more than six years. Q-medical and dental clinic is currently experiencing a period of business development in order to survive in the future. Management of the clinic-Q medical and dental sees the phenomenon of positive health service business in the future. Management captures several important things such as (a) the role of technology in health services, (b) improvement of clinical operational systems, (c) Sustainable Development Goals (SDGs) (d) service product development from Q-medical and dental clinic to the one-stop solution healthcare in the city of Bogor.

Clinic -Q medical and dental is a Pratama clinic located in the city of Bogor, engaged in general health and dental services that serve general patients. The clinic has been established for 6 years with operational time from Monday to Saturday at 07.00 21.00 WIB (Waktu Indonesia Barat/ Western Indonesian Time). Currently the clinic-Q has collaborated with laboratories and several dental laboratories at Hans Dental Laboratory and the Asian Africa dental laboratory. The growth in the number of patients from each time has an influence on the clinical development plan. It was noted that in 2014 there were 2.971 patients, which in 2015 increased by 1 -fold or as many as 6.702 patients and in 2016 increased 0.4 times from the previous year to 8.029 patients.

On the other hand, there is an increasing need for the public regarding health services, forcing every business owner to make a health service change strategy. This is in order to maintain the existence of the business and develop the business. Besides, there is a positive trend from the public regarding health services in one place with other places of visit. Increasingly developing communities, creating health services that were once more curative but are now starting to develop towards prevention. This is, of course, a more point for service providers who are able to provide these services. The issue of loving the environment is now an important thing for business people. Loving the environment is a basic obligation but can also be a business attraction. In addition, environmental preservation activities for the realization of a sustainable business become a world program through SDGs or Sustainable Development Goals. Currently clinic-Q medical and dental has carried out environmental safeguards activities in collaboration with companies engaged in infectious waste management with PT. Environmental Direction of Indonesia

Health services according to the Ministry of Health of the Republic of Indonesia in 2009 contained in the Health Act are every business that is organized alone or jointly in an organization to maintain, improve health, prevent and cure diseases and restore the health of individuals, families, groups, and communities. Management strategy, in general, has some understanding David (2011) explains management strategy is an art and knowledge in formulating and implementing and evaluating cross-functional decisions in organizations that enable it to achieve goals. Porter strength analysis is used to determine competitive advantage and company competitive advantage (Kodrat, 2009). Financial performance is an important thing that can be used to measure the level of performance of a company. This has benefits for various stakeholders such as business owners, management and the government. Darbi (2012) states that the development of a vision and mission is a basic step used for strategic planning related to the organization in the future.

The strategy formulation process can be carried out by using three stages, a framework with a matrix as a mode of analysis. The strategy formulation process is according to the concept (David, 2011) through three stages of analysis, namely input 
stage, matching stage, decision-making stage. The SDG's stands for sustainable development goals, namely a program that will become a reference in the framework of development and negotiation in the countries of the world. SDG's forms a fifteen-year framework that began in 2015 and until 2030. SDG's programs are a following-up program from MDG's (Millenium Development Goals) which aims to target and involve civil parties to be able to contribute to the program (Yohanna, 2015). Kirana (2016) stated that internal analysis using the value chain, maternity clinic requires several information systems, namely information systems for delivery and inpatient payment and information systems for the delivery of medical equipment. While external analysis uses five force porters to display the potential of the information system competitors.

In Shojaie et al. (2014) research, related to the strategic plan for the company produced a conservative strategy in the strategic planning matrix, then the market development strategy was chosen to achieve competitive advantage through market advantage, where it is based on stronger external influences so the company must make non-aggressive changes. Mahmodi et al. (2014) stated that the results of the analysis note that in the known conservative strategy can be an option in business development. Required standards in efforts to develop business and training activities of employees.

Yahzani et al. (2012) note that the use of SWOT (Strength, Weakness, Opportunity, and Threats) analysis can clearly illustrate the position of the company other than that a conservative strategy can be an option. Management needs to pay attention in developing markets and products to maintain and find new opportunities in business. Likewise according to Ghosiyan (2015) management can develop businesses, where the focus is on marketing activities and forming communities that are loyal to their business.

Farhoodi (2011) by using the SWOT and QSPM (Quantitative, Strategic, Planning, Matrix) approaches the company found out that it had to develop. Efficient marketing is chosen based on the results of the analysis as an alternative to maintaining current conditions. In Abya's (2015) research in India, it is known that companies can carry out aggressive strategies, but in this case, companies need to pay attention to nature protection to be able to survive in their business activities.

Isnandar et al. (2016) the use of QSPM in determining the best strategy can provide a good picture, due to the choice of strategies that can be used. Ahmad (2016) SWOT analysis found that companies must develop with a focus on providing information to customers. On the other hand, today businesses need concrete steps to improve the environment.

\section{Methods}

The study was conducted at the clinic-Q medical and dental, located on St. Tentara Pelajar No. 20 G Bogor City West Java Indonesia. The selection of clinic-Q as the object of this research was based on existing problems, consideration of data availability and the willingness of the company to study its management strategy study. The research period is conducted from February 2018 to April 2018. This study uses primary and secondary data. Primary data is obtained through interviews and discussions using the focus group discussion (FGD) method for the clinic-Q who has the authority to determine decisions for the company and understand the research topic. 
The informants of the research are doctors, environmental experts, hospital leaders, programmers and consumers.

Determination of respondents in this study was chosen by proportional random sampling. In the data retrieval process is done in two ways, namely in-depth interview, which is a process of obtaining information for research purposes by way of question and answer conducted by face to face between interviewers with respondents (informants) using interview procedures (Sugiyono, 2010) and focus group discussion is a technique used to carry out data collection conducted by discussion techniques.

\section{The Analytical Method}

Descriptive analysis aims to identify external, internal activities at the clinic-Q medical and dental. This analysis is used to see the real situation of the business development plan. In addition, descriptive analysis is used in determining information in vertical processing in process hierarchy analysis. The type of data that will be presented in the study is quantitative (calculation) and qualitatively descriptive.

Financial performance analysis in this study uses several ratio calculations including profitability and activity ratios. The use of this calculation is based on the conditions that exist in the company which is the object of research QSPM (Quantitative Strategic Planning Matrix) Analysis were formulating the process stages of the strategy in determining the strategy is three stages, consisting of input stage, matching stage, and finally decision stage.

\section{Findings}

\section{Clinic Background}

The background of the clinic is the history of the Q-clinic itself. Based on the letter of the license for the clinic with the number, the Q-clinic was established with the full name or the origin name in Bahasa is "Klinik-Q Medical \& Dental" in 2011 and began on May 31, 2012. Clinic-Q is located on St. Tentara Pelajar No 20 G, Bogor Tengah City sub-district, Bogor, West Java, Indonesia. The founder of the clinic was by Dr. Umi Zakiyah also concurrently as a doctor in charge of the Q-clinic.

\section{Clinical Financial Performance Analysis}

Financial performance analysis is used to determine the progress of clinical activities each year. The information about financial reports available at the clinic is presented in several models those are from the profit and loss that can be seen in Table 1 and the financial ration of the Q-clinic that can be referred to Figure 1.

Table1 Profit and Loss 2015-2017

\begin{tabular}{llrrrrrr}
\hline Code & Description & \multicolumn{2}{c}{2015} & \multicolumn{2}{c}{2016} & \multicolumn{2}{c}{2017} \\
\hline A & Sales & IDR & 1.453 & IDR & 1.794 & IDR & 1.967 \\
B $($ var cost $)$ & COGS Dental & IDR & 93 & IDR & 101 & IDR & 118 \\
C $($ var cost $)$ & COGS General & IDR & 62 & IDR & 67 & IDR & 78 \\
D=B+C & Total COGS & IDR & 155 & IDR & 169 & IDR & 196 \\
E=A-D & Gross Profit & IDR & 1.298 & IDR & 1.624 & IDR & 1.770 \\
F $($ var cost $)$ & Operational Dental & IDR & 345 & IDR & 393 & IDR & 407 \\
G $($ var cost $)$ & Operational General & IDR & 192 & IDR & 218 & IDR & 226 \\
H $($ fix cost $)$ & Operational Staff & IDR & 153 & IDR & 175 & IDR & 181 \\
I $($ fix cost $)$ & Operational Clinic & IDR & 176 & IDR & 187 & IDR & 190 \\
J & Depretiation & IDR & 6 & IDR & 7 & IDR & 0 \\
\hline
\end{tabular}




\begin{tabular}{|c|c|c|c|c|c|c|c|}
\hline Code & Description & \multicolumn{2}{|c|}{2015} & \multicolumn{2}{|c|}{2016} & \multicolumn{2}{|c|}{2017} \\
\hline $\mathrm{K}=\mathrm{F}+\mathrm{G}+\mathrm{H}+\mathrm{I}+\mathrm{J}$ & Total Operational Cost & IDR & 768 & IDR & 875 & IDR & 905 \\
\hline $\mathrm{L}=\mathrm{E}-\mathrm{K}$ & Earning & IDR & 426 & IDR & 644 & IDR & 766 \\
\hline
\end{tabular}

The financial ration of the Q-clinic can be seen on the Figure 1. The financial ration consists of NPM (Net Profit Margin) ratio, ROI (return on investment), TATO (total asset turnover), and ITO (inventory turnover ration). From the figure below, presented the financial ration of the Q-clinic from 2015-2017.

NPM

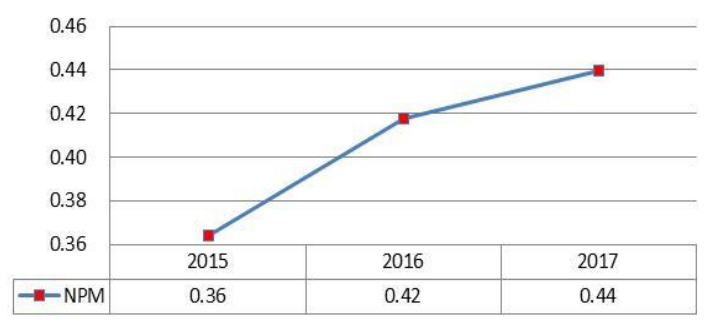

TATO

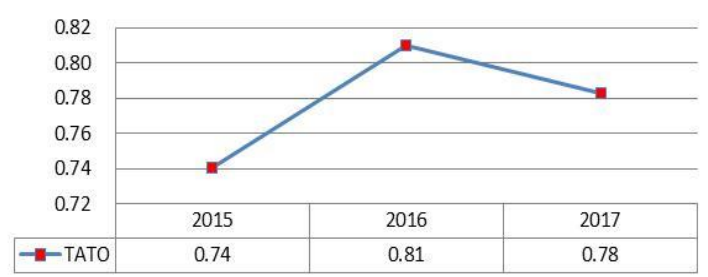

ROI

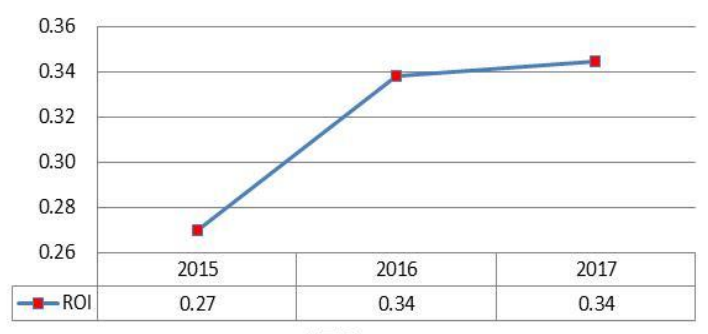

ITO

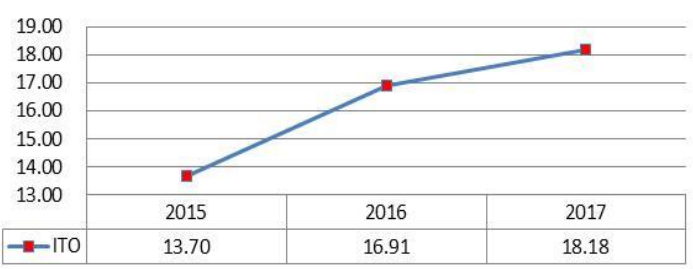

Figure 1 Financial Ratio

\section{SWOT Analysis}

The SWOT analysis is used in this study as a determination of alternative strategies related to strengths, weaknesses, opportunities, and threats of the business being run. It is known that through SWOT analysis there will be several alternatives based on the SWOT matrix with qualitative approaches and quantitative approaches. That in general the strength of the clinic is 11 indicators, weakness as many as three indicators, opportunity as many as eight indicators and threat as many as six indicators. Assessment of SWOT analysis refers to the value of the external and internal analysis that has been carried out. The value of stress is 3.15 , weakness is 0.13 , opportunity is 2.18 and threat is 0.84 . Calculations are carried out using a quantitative approach to SWOT, can be seen in Figure 2. 


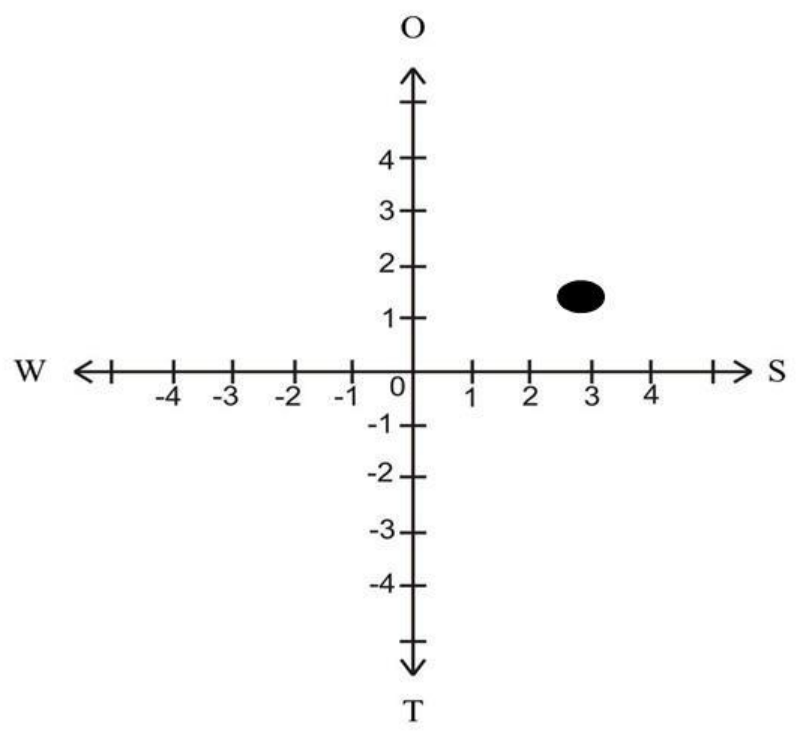

Figure 2 SWOT Analysis with Quantitative Approach

It is known from Figure 2 the alternative strategy position using the SWOT analysis approach obtained in quadrant 1 . Where in the quadrant 1 the clinic must take aggressive steps in order to develop its business.

\section{Formulation of External Internal Strategies}

The strategy formulation is obtained from the results of the internal and external evaluation position. By using the actual positioning of the clinic it is very important to use it for: the role in determining alternative strategies. It is known that the strength value of the clinic is 3.15 and the weakness is 0.13 where the total internal value is 3.28. While the opportunities of the clinical business environment are known to have a value of 2.18 and a threat of 0.84 so that the total is 3.03. Determination with IE (Internal and External) matrix according to the one presented in Figure 3.

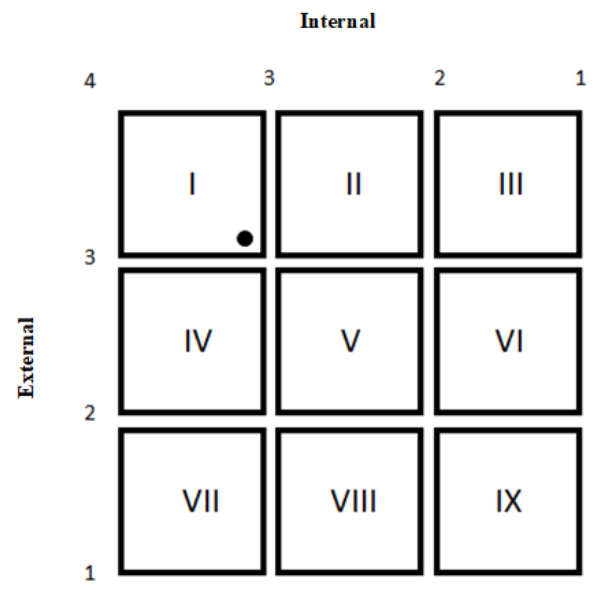

Figure 3 Matrix IE Q Medical \& Dental Clinic

It is known that the position of the clinic in the IE Matrix is in position I. David (2011) explained that quadrants I, II and IV have the same alternative strategies, namely 
grow and development. So that all recommendations from these positions aim to focus on business development and growth. There are a number of alternative strategies including; 1) Backward, forward or Horizontal Integration. Basically, this strategy focuses on business development from upstream to downstream. Hence, the certainty of the business will be better than before. There are recommendations for implementing ways to collaborate with various health businesses such as new clinics and or pharmacies; 2) Market Penetration. In the market penetration, it is known that it focuses on increasing the market share with existing products, which conduct massive marketing activities. In this type of clinic can implement through brand development activities by using celebrity endorsement or other famous influencers; 3) Product Development. An alternative form of product development strategy is explained as a form of existing product development. This can be done by clinics by creating complementary products from businesses that have been run.

\section{Analysis QSPM}

The preparation of QSPM (Quantitative Strategic Planning Matrix) analysis is based on the results of the analysis of the Internal and External Matrix. It is known that the matrix is obtained at the position of quadrant 1 so that the formulation of the priority strategy must be related to growth and development. The formulation of priority strategies is based on expert recommendations and the results of interviews with clinic owners. The choice of priority strategies in Table 2 .

Table 2 Priority Strategies with QSPM

\begin{tabular}{lcccc}
\hline \multicolumn{1}{c}{ Information } & Skin Healthcare & Promotion & System & Clinic Change \\
\hline Strength & 3.32 & 2.87 & 3.14 & 2.78 \\
Weakness & 0.20 & 0.19 & 0.18 & 0.17 \\
Opportunity & 1.90 & 1.95 & 1.84 & 1.78 \\
Threat & 1.07 & 0.94 & 1.01 & 1.03 \\
Total TAS & 6.485 & 5.947 & 6.17 & 5.76 \\
\hline
\end{tabular}

The decision making the stage of the priority strategy using QSPM, calculations are made on the relative attractiveness of various internal and external factors contained in the strategy formulation. Furthermore, each weight obtained from internal and external is then multiplied by the resulting value to get the total value of attraction. The results of the total attraction value are then sorted as a form of recommendation for the clinical priority strategy. The results of the priority strategy are obtained for the total attraction value as follows; 1) The Product Development Strategy described by opening skincare $\&$ healthcare units earns points of 6.485 ; 2) The Horizontal Integration Strategy illustrated by improvement in the clinical management system gets points of $6.17 ; 3$ ) The market penetration strategy illustrated through increased marketing activities gained 5.947 points; 4) The product development strategy illustrated through business diversification gets a value of 5.761 .

The results of the alternative strategy formulation are then made several programs to get the best implementation recommendations, while among others:

1. Product Development Strategy 1

It is known that this strategy has the highest attraction value of 6,485. Basically Klinik-Q Medical \& Dental has a large market in the city of Bogor, but until now it still often has problems in serving its patients. The programs that can be 
done include extending the clinic area by buying a shop in the same location, open a new poly that serves skincare, open several new rooms for the poly that are already running, and in the opening process, a new place must have a design that can invite to love the environment.

2. Horizontal Integration Strategy

It is known that this strategy has a value of attraction of 6.17 clinic-Q medical and dental is aware that the management system currently being implemented is still not good amidst the rapid competition. The recommended programs are using computerized activities. This is so that all patient data and information can be stored properly, make a better financial system. In its application, patients can make transactions with various payment methods. In addition, this is done by repairing the financial activity registrar in order to get financial statements that are in accordance with the rules, make operational system improvements, especially scheduling with doctors, and cooperating with plant maintenance services to play an active role in greening the surrounding environment

3. Market Penetration Strategy

The market penetration strategy has a value of 5.947. The programs that are well done by clinics include increasing the brand image of clinic-Q Medical \& Dental in the eyes of the public. This can be done by visiting several schools. In addition to making an invitation through social media to the public, use social media for active promotion. Where clinic managers can use paid facilities from social media to get better expectations and results and use the celebrity endorser to cover activities and services at the clinic-Q medical and dental.

4. Product Development Strategy 2

It is known that this strategy has the highest attraction value of 5.76. This strategy was carried out because of the need to change the clinical business model from Pratama to the main. On the side of seeing the existence of the JKNBPJS policy providing new potential in market development, with this, the clinic can collaborate with BPJS in order to increase the number of patient visits. The programs that can be done include extending the clinic area by buying shop houses in the same location to serve inpatients, increase the number of specialists and doctors / dentists and open new poly, cooperating with BPJS in public health and dental services, and in the opening process a new place must have a design that can invite to love the environment.

\section{Managerial Implications}

Based on the results of the research related to alternative strategies and decision making based on QSPM analysis tools. However, the implications formulated can be seen as follows; a) Product development, basically the strategy of product development that can be done by clinic-Q medical \& dental related to product development is to create new businesses, namely skin \& healthcare. This is considered important considering the growth of beauty clinics in 2016 reached 2016 and will continue to increase each year from this it is clear that the formation of new poly has the potential to provide additional revenue for the clinic; b) Integration strategy, clinic-Q medical and dental acknowledges that the clinical system is still conventional. Where that still uses a combination of computer usage and recording with a simple book. The recommendation that needs to be done by Q medical and dental clinic at first is to improve the financial 
registrar. This can be done using financial software that can be integrated with personal computers and smartphones; c) Market penetration strategy, clinic-Q medical and dental realizes that currently there are many patients. On the other hand, clinic-Q must start building a brand image from the clinic so that a good image remains in the community. The transfer of patients from one clinic to another is very easy to happen, besides that a large number of patients who are not aware of the importance of health is also a potential income in the future.

\section{Conclusion and Recommendation}

\section{Conclusion}

The financial performance of the clinic-Q medical and dental clinic shows growth with varying amounts in each year. Also, to the several ratios used in describing the performance of the clinic also showed good growth. So, it can be said that clinic-Q can have the potential to be developed more.

The factors that play significant role in business development from the internal and external side show the position in quadrant I, which interpreted the choices for business development. In addition, the SWOT approach also shows the choice to use aggressive strategies that can be interpreted as development. Therefore, a number of recommendations for appropriate strategies to be implemented are product development, horizontal integration, and market penetration.

Strategies that are in accordance with the SDGs concept that can be done now by the clinic are increasing plant planting around the clinic, reducing the use of plastic, carrying out maintenance of liquid waste disposal and maintaining cooperation in managing medical waste clinics to PT ARAH environmental.

\section{Recommendation}

The several important suggestions in this study are the Implementation of the strategy in the form of an action plan is an important thing that needs to be sought by management to facilitate achieving company goals. Besides, strategy is an important thing that needs to be studied more deeply, it needs to be studied further related to the clinical market share of various types next review.

\section{References}

Abya, H., Khalili, M., Ebrahimi, M., \& Movahed, A. (2015). Strategic planning for tourism industry using SWOT and QSPM. Management Science Letters, 5(3), 295-300.

Ahmad, A. P. (2016). Determining A Proper Vitality Strategy In Historical Areas Of Tehran Through Qspm And Iea Analysis Methods. The Turkish Online Journal Of Design, Art And Communication, 9(1), 1021-1035.

[BPS] Badan Pusat Statistik. (2016). Survei Demografi dan Kesehatan Indonesia 2016. Jakarta, Indonesia : Badan Pusat Statistik.

Bank Data Bogor. (2017). Data Kota Bogor 2017. Bogor, Indonesia : Pemkot Bogor.

Darbi, W. P. K. (2012). Mission and Vision Statements and their Potensial Impact on Employee Behavior and Attitude : The Case of A Public But Profit-Oriented 
Tertiary Institution. International Journal of Business and Social Science, 3(14), 95-109.

David, F. R. (2011). Strategic Management Manajemen Strategi Konsep. Jakarta, Indonesia : Salemba Empat.

De Ven, A. H. (2014). What Matters Most To Patients? Participative Provider Care And Staff Courtesy. Patient Experience Journal, 1, 1-12.

Deloitte. (2015). Conncted Health, How Digital Technology Is Transforming Health And Social Care. New York: Deloitte Centre for Health Solutions.

Farhoodi, R., Gharakhlou, N. M., Ghadami, M., Khah, M. P. (2009). A critique of the prevailing comprehensive urban planning paradigm in Iran: The need for strategic planning. Planning Theory, 8(4), 335-361.

Ghosiyan, A., Ebadi, M., Shojazadeh, A. (2015). The Quantitative Strategic Planning Matrix (QSPM) Applied To Sport in West Azerbaijan Province. International Journal of Sport Studies, 5(1), 124-128.

Isnandar, F. R., Firdaus, M., Maulana, A. (2016). Strategi Peningkatan Aset PT BPR Syariah Harta Insan Karimah (HIK) Ciledug. Jurnal Aplikasi bisnis dan Manajemen, 2(1), 12-25.

[Kemenkes] Kementerian Kesehatan. (2015). Rencana Strategis Kementerian Kesehatan Tahun 2015-2019. Jakarta, Indonesia: Kemenkes. (2018). Peraturan Menteri Kesehatan Republik Indonesia Nomor 40 Tahun 2018. Jakarta, Indonesia: Kementerian Kesehatan.

Kirana, E. K. (2016). Perencanaan Strategis Sistem Informasi Klinik Bersalin Bunda Banjarbaru. Indonesian Journal On Software Enginering, 2, 1-10.

Kodrat, D. S. (2009). Manajemen Distribusi. Yogyakarta, Indonesia: Graha Ilmu.

Mahmoudi, B., Haghsetan, A., Maleki, R. (2011). Investigation of Obstacles and Strategies of Rural Tourism Development Using SWOT Matrix. Journal of Sustainable Development, 4(2), 136 - 141.

Shojaie, M., Taheri, N. S., Mighani, M. A. (2014). Strategic Planning For Parsa Chemical Industry Company Using Swot Analysis, Qspm Model (One Of The Top Companies Of Iranian Paint). Public Policy And Administration Research, $1(1), 171-180$.

Sugiyono. (2010) . Metode Penelitian Pendidikan Pendekatan Kuantitatif, kualitatif, dan $R \& D$. Bandung, Indonesia: Alfabeta.

Thimbleby, H. (2013). Improving safety in medical devices and systems. Proceedings IEEE International Conference on Healthcare Informatics, 14, 29-38.

Yahzani, M., Larijani, A. L., Zarimohaleh, S. T., Monavarian, A. (2012). Developing Optimized Strategy by Comprehensive Framework of Strategy; Case Study in a Construction Inspection Company. Social and Behavioral Sciences, 58(1), 73-83.

Yohanna, S. (2015) Transformasi Millenium Development Goals (MDG's) menjadi Post 2015 Guna Menjawab Tantangan Pembangunan Global Baru. 